\title{
Determinanty a aplikace herních aktivit osob se specifickými potřebami
}

\section{Determinants and applications gaming activities for persons with disability}

\author{
Jan Křiček \\ Fakulta tělesné výchovy a sportu, Univerzita Karlova, Praha, \\ Česká republika
}

\begin{abstract}
Abstrakt:
Vzdělávání, výchova a začleňováni do společnosti osob s disabilitou je trvalým cílem speciálních školních institucí. Významnou pozici $v$ kurikulech vzdělávání žáků těchto škol zaujímaji také sportovní programy s herním obsahem (pohybové hry, modifikované sportovni hry, cílové sporty). V tomto prostředi je aplikace těchto aktivit poznamenána didaktickými odlišnostmi a dílč́mi diferencemi. Vyjádřeny jsou výběrem a uspořádáním učiva, jeho didaktickou redukcí, aplikovanými didaktickými formami, úpravami pravidel. Přiznivý dopad hernich aktivit mezi zdravotně postiženými se efektivně projevuje predevšim v oblasti psychické a socializační.
\end{abstract}

\section{Abstract:}

Education of people with disability is a permanent objective of special educational institutions focused on their integration into society. An important position in the education curriculum of these students is occupied by sports programs with gaming content (motion games, modified sports games, target sports). Application of game activities among disabled people is marked by didactic differences. The differences are expressed by didactic reduction of curriculum, by selecting and orga- 
nizing the curriculum, applied didactic forms, modifications of the rules as well. The positive effect of the appliation of game activities among disabled manifests itself especially in the psychological and socialization area.

Klíčová slova: vyučování, hry, didaktika, postupy.

Key words: teaching, games, didactics, procedures.

\section{ÚVOD}

V posledním dvacetiletí došlo k výraznému zlepšení životních podmínek osob se specifickými potřebami, s menším časovým zpožděním dochází i k jejich postupnému začleňování do společnosti. Integrace osob s disabilitou se v současnosti uskutečňuje na několika oborových úrovních, participují na ni významné státní rezorty, společenská nezisková sdružení a organizace včetně dobrovolných zájmových klubů. Jednu z rozhodujících pozic $\mathrm{v}$ kontextu jejich integrace zaujímá prostřednictvím sítě speciálních institucí resort školství. K integraci, edukaci a kultivaci žáků přispívá významnou měrou také organizovaná tělesná výchova a sport. Relativně dominantní pozici si v tomto směru udržují pohybové aktivity s herním obsahem (pohybové hry, průpravné hry, modifikované sportovní hry, cílové sporty). Díky širokému potenciálu zejména pak hry jsou v daném prostředí jedinečným zdrojem nejen uspokojování žádoucí biologické a prožitkové sféry žáků, ale též důležitým činitelem formování jejich vztahu k pohybové aktivitě a sportu (Dobrý, 2003).

\section{CÍL}

Cílem př́spěvku je poukázat na priority pohybových aktivit $\mathrm{s}$ herním obsahem a funkčnost jejich aplikace ve sledovaném prostředí. S ohledem $\mathrm{k}$ šíŕi typů disability se v textu zaměřujeme na priority a předpoklady těchto aktivit v kontextu vyučování (obsah, učební podmínky, postupy). Cílem textu tak není vymezení dimenzí vyučování s tímto obsahem, ale 
Determinants and applications gaming activities for persons with disability

Determinanty a aplikace herních aktivit osob se specifickými potřebami

didaktická doporučení, jak s ohledem k vyučovacímu cíli v daném prostředí (kultivace osobnosti) efektivně postupovat.

\section{HLAVNÍ ČÁST}

\section{Herní aktivity (charakteristika)}

Sporty s herním obsahem zaujímají mezi cílenými pohybovými aktivitami určující pozici. Podílí se na tom především jejich variabilita, atraktivita, emocionálnost, ale i jejich tradice, mediální benefity a relativně snadná dostupnost. Pohybové aktivity s herním obsahem (dále HA), zahrnující malé a velké pohybové hry, průpravné hry a sportovní hry včetně cílových sportů, jsou svým univerzálním obsahem a polyfunkčním charakterem jedinečné. Současně uspokojují zájmy a potřeby jedince (biologické, psychologické, sociální) a svou proměnlivostí vytvářejí široký prostor tvorby nových situací. Podle Kábeleho (1992) přispívají k aktivizaci celé osobnosti. Působí jako vyvážený biologický činitel k udržení zdraví, navýšení zdatnosti a výkonnosti, parciálně i jako činitel preventivní a rehabilitační. Nenásilným a přirozeným způsobem proměňují tělesné zatěžování v zábavnou prožitkovou činnost s výraznou efektivitou - rozvíjejí tělesnou zdatnost a výkonnost s ,minimální námahou a maximálním účinkem“ (Křiček, 2004). HA jsou také, a to v celém svém průběhu, činnostmi nasycené intenzivními emocemi a prožitky. Navozují dobrou náladu a radost z pohybu, přispívají k uvolnění a snížení celkového napětí a podílejí se na kvalitě postojů $\mathrm{k}$ pohybové aktivitě. Variabilitou herních situací vytvářejí jedinečný edukační prostor pro motorické učení, ovlivňování psychomotorických schopností, senzoriky, kognitivních procesů a osobnostních vlastností jedince (Hošek, 2000). HA jsou v prevalenci aktivitami kolektivními. Týmová synergie a koheze jsou unikátními činiteli seberealizace a socializace aktéra, utváření jeho vztahů přesahující hranice jeho okolí. Intenzita a suma prožitků spojená s provozováním HA vytvářejí předpoklad, že aktér sportuje na základě vlastního rozhodnutí dobrovolně, často opakovaně a v mnoha situacích bez zřetele k vynakládanému úsilí a času. 


\section{Předpoklady aplikace}

O významu aktivního sportování, s přihlédnutím ke snižujícímu se podílu pohybu $\mathrm{v}$ životě dnešní populace a zvyšujícímu se počtu civilizačních chorob, dnes pochybuje málokdo. Co platí o pohybu z hlediska zdraví u majoritní komunity, o to těsněji se potřeba pohybové aktivnosti vztahuje k osobám s limitacemi (Lejčarová a Jansa, 1998). V důsledku narušení některé z funkcí (metabolické, neurohumorální, somatické, psychické) tyto osoby většinou nedisponují dostatečnou úrovní pohybových schopností a dovedností ani potřebnou úrovní tělesné zdatnosti a adaptace. $\mathrm{V}$ důsledku celkové deprivace nedisponují ve většině ani odpovídajícími možnostmi komunikace či účasti na veřejném životě. V prostředí těchto osob se tak provozování aktivního pohybu evidentně jeví jako společensky potřebné, nutné a žádoucí. Prospěšnost aktivního sportu mezi osobami se specifickými potřebami (dále OSP) potvrzuje celá řada studií a to jak $v$ horizontu jejich edukace, tak jejich zájmových a volno časových aktivit. Z komparace těchto studií vyplývá, že v rejstř́ku pohybových aktivit se nejvíce prosazují hry a aktivity s herním obsahem. Tuto výsadní pozici ve spektru ostatních aktivit umocňují, vedle zážitkové sféry, především jejich sociálně integrační efekty. Potřeba sounáležitosti, komunikace, vzájemného setkávání, porozumění, seberealizace včetně soutěživosti jsou právě těmi hodnotami, které tyto osoby na HA oceňují nejvíce (Potměšil, 1998). Socializační efekt těchto aktivit potvrzují také některé sociologické studie. Hošek (1997) uvádí, že aktivity se skupinovou dynamikou a zejména hry, produkující intenzivní prožitky prostoupené emocemi, poskytují nejvíce socializačních a integračních prŕležitostí a nejlépe odpovídají lidské potřebě afiliace, potřebě sounáležitosti a lidské identifikace. Oproti intaktním osobám, má hra v okruhu těchto osob, výrazně hlubší dosah. Dle Kábeleho (1992) nabývá širšího rozměru, stává se uznávanou životní hodnotou, novým horizontem realizace a sebeuvědomění, stává se činností, která má smysl. K navýšení hodnoty hry zde přispívá také její variabilnost (Dobrý, 2003). Rychle se měnící prostředí, nutnost samostatného řešení úkolů a zaujímání nové role v nestandardních podmínkách hry podněcuje 
jejich myšlení, ovlivňuje psychickou odolnost a celkovou adaptaci. HA v této úrovni tak transparentně naplňují motto zakladatele sportu handicapovaných L. Guttmana: , sport je pro postiženého hybnou silou pomáhající mu obnovit vztah k okolnímu světu a k uznání sebe jako plnoprávného občana“.

S aplikací HA mezi OSP se setkáváme ve školských zařízeních, dobrovolných společenských sdruženích a zájmových organizacích. Jejich širokého funkčního záběru využivá zejména organizovaná tělesná výchova, která je v mnoha př́padech jedinou příležitostí aktivního pohybu a pohybového vyžití žáků. Přestože HA si v rámci tělesné výchovy na většině těchto škol udržují výsadní postavení, na některých dokonce dominantní, zůstává jejich praktická aplikace stále za možnostmi a očekáváním. Tato současná nevyváženost, přes viditelná zlepšení, však není vyvolána absencí odborného personální zázemí či materiální limitace. Př́ičinami jsou především pochybnosti a skepse ze strany učitelů v kontextu aplikace HA s nimiž se ještě i dnes setkáváme. Snad s přihlédnutím k faktu že učitel nedisponuje znalostmi, popř. zkušenostmi s herním prostředím a tak postrádá patřičnou „odvahu pro hry“. Snad s přihlédnutím k tomu že zejména sportovní hry jsou, jak konstatuje Rychtecký (2008), obtížněji uchopitelné a učitel podléhá obavě vyšší organizační náročnosti, př́ípadně zranění či úrazu žáků.

\section{Aplikace mezi OSP}

Klíčovou roli při aplikaci HA mezi OSP sehrává učitel. Přímá aplikace těchto aktivit je spojena s didaktickými okruhy otázek vztahujícími se k obsahu a postupům vyučování. Prvý z okruhů se vztahuje k výběru a uspořádání učiva a k didaktické otázce „,co aplikovat?“, druhý k vytváření učebních podmínek a k didaktické otázce ,jak aplikovat?“ (Psota \& Velenský, 2009).

Výběr HA přestavuje pro odpovědného učitele vždy náročný úkol, zde jeho obtížnost navyšují zdravotní limitace žáků. Doporučujeme proto provádět výběr HA na základě cílené analýzy daného prostředí (učební podmínky, dispoziční úroveň, herní a sociální zkušenosti OSP) a predik- 
ce postupů. Přri vlastním výběru hry ale nepostupujeme dogmaticky, neopomíjíme zejména inklinaci a zájem žáků k dané HA, zohledňujeme také podmínky její realizace.

Z hlediska charakteru vyučování HA v prostředí OSP, obdobně jako v intaktním prostředí, se evidentně jedná o binární (dvojstranný) proces odpovídající obecným didaktickým kriteriím, kladených na každé vyučování školského zařízení. Dobrý (1988) jím rozumí souběžný rozvoj edukace a osobnosti jedince naplňovaný paralelně, zvyšováním úrovně dovedností (nácvik, zdokonalování) a zvyšováním tělesné zdatnosti (funkční zatěžování). Přestože základní linii vyučování představuje rovnoměrně vyvážený rozvoj (dovednosti, funkce), jeho těžiště je v tomto prostředí přesouváno více na rozvoj dovedností žáků (osvojování, zdokonalování). Funkčnímu rozvoji v rámci vyučování nevyčleňujeme speciální prostor, uskutečňuje se totiž souběžně a nenásilně prostřednictvím nácviku, osvojování a zdokonalování herních dovedností.

Samotný nácvik včetně zdokonalování, vzhledem k otevřenému charakteru herních dovedností, nárokuje zvýšenou pozornost a koncentraci žáků. Nácviku tak předchází, jako jeho vhodný předstupeň, rozvoj percepce, stability, prostorové a vizuální orientace. Nezapomínáme také na navození potřebné herní atmosféry prostřednictvím „herní předehry“, např. jednoduchou hrou, kterou žáci dobře znají a mají ji zažitou.

Didakticky nezastupitelnou pozici sehrává v rámci nácviku ukázka osvojované herní dovednosti. Evidentnost a transparentnost dovednosti je primární determinantou jejího úspěšného osvojení a zafixování žákem. Větší časový prostor věnovaný ukázce ze strany učitele a také „více ukázek méně slov“ zde platí dvojnásob.

Herní nácvik považujeme za integrálně určující část aplikace těchto aktivit. S ohledem k disabilitě žáků využíváme ve vyučování elementární didaktické redukce, tj. dílčího zjednodušení herních dovednosti (činností). K redukci přistupujeme však pouze za předpokladu, že simplifikace neohrožuje charakter dovednosti ve své podstatě. Pokud žáci disponují určitým počtem dovedností (zásobníkem), flexibilně jich využíváme. 
Formu „herního tréninku“ využíváme v rámci vyučování ve fázi osvojování a zdokonalování herních dovedností (zvyšování úrovně). Dle učebních podmínek postupujeme cestou situační didaktické redukce, tj. zjednodušením herních situací, které se v průběhu hry vyskytují. Dominantní roli pro přijetí didaktické redukce (elementární, situační) sehrává opět učitel, resp. jeho akademičnost, pod kterou Rychecký (2000) zahrnuje komplex vědomostí, dovedností, kompetencí, potřebnou dávku pedagogického mistrovství, didaktické invence, tvořivosti, formulační jistoty a žádoucí míru flexibility.

Vlastní realizace HA je spojena s vytvářením a manipulací učebních podmínek. Také zde, obdobně jako při výběru hry, se opíráme o didaktické postupy praktikované ve vyučování intaktních osob. V reflexi disability různé úrovně včetně prostředí ale uplatňujeme jisté odlišnosti spojené s výběrem didaktických forem i didaktických metod. K stabilizaci nově osvojených dovedností využíváme, na základě dovedností již žákem fixovaných, zejména herní cvičení, průpravné her a sportovní hry s modifikacemi. Účelem aplikace uvedených forem je udržet zájem a aktivitu žáků v průběhu celého vyučování (Velenský, 2005). Průpravnými hrami nebo modifikovanými sportovními hrami usilujeme o maximální přiblížení ke hrám standardního typu, prostřednictvím herních cvičení alespoň k jejím úsekům, které se v dané sportovní hře opakovaně promítají.

Pravidla průpravných her a zejména modifikovaných sportovních her přizpůsobujeme dle úrovně herní způsobilosti (dovednostní) žáků, nebot' se může značně lišit. U žáků začátečníků, aby došlo k realizaci hry vůbec, doporučujeme propojit pravidla sportovních her s pravidly tzv. malých pohybových her. $\mathrm{K}$ úpravě pravidel lze prisstupovat bud' cestou zjednodušení standardních pravidel, vymezením tzv. základních pravidel, nebo cestou jisté míry tolerance vůči porušování pravidel v průběhu utkání (Křiček \& Velenský (2013). Tento druhý způsob si však nárokuje dávku herní zkušenosti učitele (rozhodčího).

S úspěšností aplikace HA také koresponduje vytváření přirozeného prostředí se zřetelem k osobnosti žáků, přirozené motivace k HA a př́znivého sociálního klimatu jako výsledku didaktické interakce. 


\section{ZÁVĚR}

Určujícím trendem vyučování tělesné výchovy v každém prostředí je snaha přizpůsobit jeho obsah potřebám, zájmu a schopnostem žáků. Tento trend uplatňujeme také při aplikaci HA mezi OSP. Efektivita vyučování s tímto obsahovým záběrem je však podmíněna respektováním určitých diferencí a odlišností postupů (výběr a uspořádání učiva, didaktické redukce, úprava pravidel). Vhodný obsah, aplikace a frekvence HA v rámci organizované výuky tak může přispívat nejen $\mathrm{k}$ uspokojení žádoucí prožitkové sféry a k celkové kultivaci žáků, ale i k ovlivňování jejich postojů k aktivnímu pohybu, sportu a životu celkově.

\section{LITERATURA}

Dobrý, L. (2003). Přehledná studie o vývoji a současném stavu zkoumání herního výkonu a jeho osvojování. In Dobrý, L. \& Souček, O. (eds.) Pedagogická kinantropologie 2003. Sborník sekce pedagogické kinantropologie Kinantropologické společnosti (pp. 36-87). Praha: Karolinum.

Dobrý, L. (1988). Didaktika sportovnich her. Praha: SPN.

Hošek, V. (2000). Pojetí psychosociálních funkcí pohybových aktivit v kontextu kvality života. In: Psychosociálni funkce pohybových aktivit v životním stylu člověka (p. 5-7). Praha: UK FTVS.

Hošek, V. (1997). Pohyb a kvalita života. Těl. Vých. Sport Ml., Vol. 63, No. 7, 7-9.

Kábele, J. (2005). Sport vozíčkářù. Praha: Olympia.

Křiček, J. (2004). Prožitková reflexe her. In. Prožitek a tělesnost. Sborník př́spěvků konference FTVS. Praha: Asociace psychologů ČR.

Křiček, J. (2005). Hry mezi zdravotně postiženými. In. Pohybové aktivity a zdraví člověka. Sborník př́spěvkủ vědeckého seminářre KTVUJP. Ústí n/L: UJP.

Křiček, J., \& Velenský, M. (2013). Modifikace korfbalu pro školní TV. Tél. Vých a Sport Mlád. Vol. 79, No. 2, pp. 22-28.

Lejčarová, A., \& Tilinger, P. (2002). Pohybové aktivity - významný fak- 
tor ovlivňování kvality života u osob s mentální retardací. In: Sport a kvalita života. Praha: UK FTVS.

Potměšil, J. (1998). Sport jako integrační činitel u osob s tělesným postižením. In: Problematika pohybových aktivit seniorů a zdravotně postižených. Souhrn př́spěvkü. Praha: UK FTVS.

Psotta, R., \& Velenský, M. (2009). Základy didaktiky sportovních her. Praha: Karolinum.

Rychtecký, A. (2008). Psychologické aspekty hry a herního chování. In E. Charvát, Hry 2008: výzkum a aplikace. Sborník mezinárodní vědecké konference (p. 135-139). Plzeň: ZČU.

Rychtecký, A., \& Fialová, L. (2000). Didaktika školni TV. Praha: UK Karolinum.

Velenský, M. a kol. (2005). Průpravné hry. Praha: Karolinum.

\section{KONTAKT:}

PhDr. Jan Křiček, CSc., kricek@fttvs.cuni.cz 